\title{
GCU
}

Glasgow Caledonian

University

University for the Common Good

\section{Everyone a changemaker? Exploring the moral underpinnings of social innovation discourse through real utopias}

Teasdale, Simon; Roy, Michael J.; Ziegler, Rafael; Mauksch, Stefanie; Dey, Pascal; Raufflet, Emmanuel B.

Published in:

Journal of Social Entrepreneurship

DOI:

10.1080/19420676.2020.1738532

Publication date:

2021

Document Version

Author accepted manuscript

Link to publication in ResearchOnline

Citation for published version (Harvard):

Teasdale, S, Roy, MJ, Ziegler, R, Mauksch, S, Dey, P \& Raufflet, EB 2021, 'Everyone a changemaker?

Exploring the moral underpinnings of social innovation discourse through real utopias', Journal of Social Entrepreneurship, vol. 12, no. 3, pp. 417-437. https://doi.org/10.1080/19420676.2020.1738532

\section{General rights}

Copyright and moral rights for the publications made accessible in the public portal are retained by the authors and/or other copyright owners and it is a condition of accessing publications that users recognise and abide by the legal requirements associated with these rights.

Take down policy

If you believe that this document breaches copyright please view our takedown policy at https://edshare.gcu.ac.uk/id/eprint/5179 for details

of how to contact us. 


\section{Everyone a changemaker? Exploring the moral underpinnings of social innovation discourse through real utopias}

Simon Teasdale ${ }^{\mathrm{a} *}$, Michael J. Roy ${ }^{\mathrm{a}}$, Rafael Ziegler ${ }^{\mathrm{b}}$, Stefanie Mauksch ${ }^{\mathrm{c}}$, Pascal Dey ${ }^{\mathrm{d}}$ and Emmanuel B. Raufflet ${ }^{\mathrm{b}}$

${ }^{\mathrm{a}}$ Yunus Centre for Social Business and Health, Glasgow Caledonian University, UK;

${ }^{b}$ Department of Management, HEC Montreal, Canada; ${ }^{c}$ Institute for Anthropology,

University of Leipzig, Germany; ${ }^{\mathrm{d}}$ People, Organizations and Society, Grenoble École de Management, France

*corresponding author simon.teasdale@gcu.ac.uk 


\section{Everyone a changemaker? Exploring the moral underpinnings of social innovation discourse through real utopias}

The term 'social innovation' has come to gather all manner of (positive) meanings from policymakers and politicians across the political spectrum. But while actors may unproblematically unite around a broadly positive perspective of social innovation as bringing about (positive) social change, we rarely see evidence of a shared vision for the kind of social change that social innovation ought to bring about. Taking inspiration from methods that recognise the utopian thinking inherent in the social innovation concept, we draw upon Erik Olin Wright's concept of 'real utopias' to investigate the moral underpinnings inherent in the public statements of Ashoka, one of the most prominent social innovation actors operating in the world today. We seek to animate discussion on the moral principles that guide social innovation discourse through examining the problems that Ashoka is trying to solve through social innovation, the world they are striving to create, and the strategies they propose to realise their vision.

Keywords: social innovation, Utopia, vagueness, Ashoka, real utopias, changemaking

Wordcount 9993 including abtsract 


\section{Introduction}

The world's most urgent task - and therefore Ashoka's core strategic focus then is to help everyone 'see' the new reality and grasp how they all can be contributors, and all be powerful, i.e., all be changemakers. Then we can all work together to tear down the new inequality and to improve how the evolving new world is designed. ${ }^{1}$

Social innovation is a dynamic concept, with meanings that continue to evolve over time and context. The original application of the term was pejorative in nature: in the $19^{\text {th }}$ Century 'social innovation' was used to counsel against utopian schemes with problematic and potentially violent consequences (Godin 2012). Nowadays, though, the term - framed as a means to 'fix our broken systems' in order to 'build a better world' (WEtech Alliance 2016) - has come to be beloved of policymakers, practitioners and academics across the globe, and across the ideological spectrum (Nicholls and Murdock 2012; Ayob, Teasdale, and Fagan 2016). Influential social innovation intermediaries have emerged, such as Ashoka - the empirical focus of this paper - with the intention to rally various actors around pathways to better futures. But while such actors may unite around the broad concept of social innovation, it is rare to see evidence of a shared vision for the kind of social change it ought to bring about (Nicholls and Murdock 2012). We are thus confronted with a seeming paradox: whereas social innovation is widely regarded as a key towards desirable futures, the contours of those futures remain mostly vague and elusive.

In this paper, we commence exploration of the aspirational vision of social innovation intermediaries by investigating how Ashoka articulate what social innovation ought to amount to. We take our cues from methods that recognise the utopian thinking inherent in the social innovation concept (Godin 2012; Jessop et al. 2013) to examine the public

\footnotetext{
${ }^{1}$ https://www.ashoka.org/en-ca/story/new-reality
} 
statements of Ashoka, one of the most prominent social innovation intermediaries in the English-speaking world today. As the theoretical basis for our analysis, we draw upon the work of the sociologist Erik Olin Wright (2009, 2012; Hahnel and Wright, 2016) on 'real utopian alternatives'. In Wright's sense, a utopia is a 'fantasy of a perfect world that fully embodies our moral ideals' (Wright 2012, 3). Adding the clarifier 'real' means recognizing the contradictions and complexities involved in realizing these ideals, and thus remaining attentive to unintended consequences and normative trade-offs. For Wright, real utopias are not empty dreams, but practical endeavours to realise fantasies that are normatively grounded on moral principles. In this spirit of real utopias, we seek to animate discussion on the moral principles that guide the public discourse of Ashoka to ask: what problems are they trying to solve through social innovation? How do they articulate a vision of the world that would be improved by the resolution of these problems? And what strategies do they propose to realise their vision of the world?

Our paper is organised as follows: First of all we elaborate on the trajectory of social innovation as a concept, showing how a collaborative social innovation discourse has evolved which leaves the end goals (or utopian visions) and/or moral principles of social innovation unspecified (Ziegler, 2017; 2019; Ayob et al., 2016). We argue that this collaborative discourse conceals different utopian visions within a rather vague reference to social change. As such, this discourse has created space for social innovation intermediaries to unite a diverse set of actors around a seemingly common cause. However, this common cause necessarily remains vague to attract as broad a range of support as possible. This leads into the (contrasting) work on real utopias, which in turn, prompts us to develop methods to explore the rhetorical repertoires and narrative strategies employed by Ashoka. Through analysis of materials published online, we identify the utopian claims inherent to public statements of this prominent 
social innovation actor. We discuss Ashoka's articulations of what is wrong with the world, their proposed solutions, and their route maps to achieving transformation. This then leads us to a wider discussion focusing on Ashoka's application of the social innovation collaborative discourse within the framework of real utopias, highlighting the possibilities and limitations of vagueness as a strategy for achieving social change.

\section{Social innovation as an academic concept}

In contrast to the appreciative reception nowadays, social innovation was first used in a pejorative sense to describe socialist ideas. The $19^{\text {th }}$ Century educational reformer William Lucas Sargant in his work 'Social Innovators and their Schemes' (1858) launched a diatribe against those 'infected with socialist doctrines', notably including such strange bedfellows as anarchist Pierre-Joseph Proudhon and moral philosopher Adam Smith (Godin 2012). 'Social innovators', according to Sargant, were utopians who failed to understand the problematic and potentially violent consequence of their projects. This negative evaluative accent of social innovation mirrored the general use of 'innovation' at this time. For instance, conservative thinker Edmund Burke referred to the French Revolution as a 'revolt of innovation' (Lepore 2014) and progressives eschewed self-identification as 'innovators' (Godin, 2012). It was probably unimaginable back in the $19^{\text {th }}$ century that actors from diverse political circles would ever unite around the concept of social innovation, but since the 2000 s social innovation has generally been used in a commendatory way by policymakers, practitioners and academics across the world, and across the entire ideological spectrum (Ayob, Teasdale, and Fagan 2016; Nicholls and Murdock 2012). This switch from negative to positive connotation of social innovation is probably indicative of a broader pro-innovation, business and market bias in policymaking and research that crept in across the course of the $20^{\text {th }}$ Century (Osborne and Brown 2011; Rogers 1962). 
Contemporary research on social innovation has emerged from different theoretical perspectives and academic disciplines (van der Have and Rubalcaba 2016). What strikes us as interesting is that these different strands of literature on social innovation appear to have recently converged (Ayob, Teasdale, and Fagan 2016) within a 'collaborative discourse' (Ziegler 2017). This presents social innovation as a collective process (Ziegler 2017; Evers, Ewert, and Brandsen 2014; Brandsen et al. 2016; Anheier, Krlev, and Mildenberger 2019) aimed at achieving social change. Within this collaborative discourse, contestation revolves around the normative question of the subsequent social change (Montgomery 2016). A utilitarian, or outcome-oriented, perspective focuses narrowly on social change as marginal improvements to quality or quantity of life, while ignoring the processes that lead to such change (Pol and Ville 2009). Conversely, a more transformational perspective focuses on social innovation more as a (democratic) process entailing the empowerment of disadvantaged groups and the restructuring of (societal) power relations (Moulaert et al. 2010): to 'fulfil an aspiration, meet a need, provide a solution to a problem or take advantage of an opportunity for action in order to change social relations, transform a framework of action or propose new cultural orientations. ${ }^{2}$ In combining both perspectives, though, this collaborative discourse risks blurring what Wright calls 'specifying moral principles' and a 'theory of transformation for realizing those alternatives' (Wright, 2012); in essence, there is no compass to help guide, anticipate and realise desirable futures.

\section{Enabling social innovation through intermediaries}

We are in desperate need of a fundamental transformation of social, economic, and cultural arrangements. The old paradigm of government aid is simply inadequate to the challenge. What we need instead are creative and innovative solutions for fostering sustainable growth, securing jobs, and increasing

\footnotetext{
${ }^{2}$ See https://crises.uqam.ca/a-propos/presentation/
} 
competitive abilities (Urama and Acheampong (2013) writing in a supplement to Stanford Social Innovation Review funded by the Rockefeller Foundation).

In practice, the collaborative discourse of social innovation encourages space for a multiplicity of perspectives to be employed (Ziegler, 2017); a broad conceptualisation of social innovation allows people with different interests, backgrounds and ideological convictions to identify with the concept, both ideologically and affectively. For example, policymakers routinely seek to exploit the mobilising power of semantic ambiguity to make social innovation palatable for a broad audience. Instructive in this regard is the European Commission which defines ${ }^{3}$ social innovation as: 'developing new ideas, services and models to better address social issues. It invites input from public and private actors, including civil society, to improve social services.' What is worth noting here is not just the breadth of the definition, but also what is left unsaid: complicated and potentially contentious issues pertaining to, for instance, democratic change and the restructuring of power relations (von Jacobi, Edmiston, and Ziegler 2017).

Intermediary organisations such as foundations or think tanks play a key role in shaping the social innovation agenda and attracting others to follow their cause. Their formal role is to offer material and discursive support, coaching and mentoring, and networking and co-working opportunities to social innovation actors (Dey and Lehner 2016). More ambitiously, they can also be seen as striving to build the field of social innovation (Nicholls 2010). By breaking down academic understandings and re-shaping them for their own purposes, they can set out processes of recognising, labelling and accrediting what counts as a 'social innovation', thus contributing to articulations of the boundaries and priorities of the field.

\footnotetext{
${ }^{3}$ https://ec.europa.eu/social/main.jsp?catId=1022\&langId=en
} 
Faced with the uncertainty of the future, actors create fictional expectations, stories and images of the future that attract others to support this future pathway, providing it with legitimacy and increasing its achievability (Ziegler 2019, 164165).

With regard to such 'fictional expectations' (Beckert 2016), social innovation intermediaries develop a linguistic repertoire - typical terms, concepts, and metaphors directed at convincing others to follow their course, often conveying a sense of urgency, as exemplified by the introductory quote to this section. In narrowing down the multiplicity of possible understandings of social innovation into more concrete definitions, methods and examples, they enact a ground in which people navigate the realisation of social innovation. Such acts of translation grant definitional and fieldshaping power to intermediaries, allowing them to declare certain matters as urgent and in need of intervention. References to 'broken human systems' and the need to 'fix' them rope the reader or listener into an imagery of 'moral shock' (Barberá-Tomás et al. 2019), painting an impression of a sinking world in need of salvation (Sørensen 2008). Thus, the stories conveyed by social innovation intermediaries become performative by compelling people to support their cause and setting out utopian ideals to which we can all aspire.

\section{From Utopian thinking to real social innovation utopias}

In 1516 Thomas More named his imaginary ideal society 'Utopia', a combination of the Greek words for 'no-place' (outopos) and 'good place' (eutopos). Utopias describe 'desired possible worlds - ideal worlds that may possibly exist, at least in imagination' (Fernando et al. 2018, 779) and 'how mankind ought to be and will be once a novel, causal structure is in place' (McBeath and Webb 2000, 1). Utopian thinking thus involves the 'proper description of ideas which when they pass over into conduct, tend to shatter, partly or wholly, the order of things prevailing at the time' (Levitas 2013, 4). 
Different from More's appraisal of imagination, nowadays Utopia is regularly used in a pejorative sense: ambitious ideas that either do not work in practice, or which have been associated with large 'blueprints' that in a top-down, authoritarian way, impose a vision inviting violence and oppression (Levitas 2017, 6). 'History is replete with disastrous utopians -' argues Hedges (2020) 'the Jacobins, the Marxists, the fascists and now, in our own age...the neoliberal imperialists.' It is not therefore not surprising that, in the social sciences, 'utopia' (writ small) has come to be used more cautiously than Utopia (writ large), which has largely fallen out of favour. Scholars have started to focus increasingly on minor, everyday 'utopian impulses' (Bloch 1995) which signal alternatives that are immediately available, and which can be sensed in every nook and cranny of the 'here and now'. As utopias have increasingly been used to connote a sense of the mundane 'desire for a better way of living and being' they figure as substantial elements of social change (Sargent 2010; Claeys and Sargent 2017). Utopian thinking often motivates people to dispute over key issues (Fernando et al. 2018), and, more indirectly, sparks engagement with critical, emancipatory political theories that, in turn, can influence grassroots innovation and the formation of social movements (Levitas 2000; Mannheim 1985).

A general framework for the analysis of 'real utopian alternatives' was developed by Erik Olin Wright $(2009,2012)$. Beginning in the early 1990s as The Real Utopias Project, Wright's work attempted not only to provoke serious discussion on alternatives to existing structures of power, privilege and inequality, but to 'focus on specific proposals for the fundamental redesign of different arenas of social institutions rather than on either general, abstract formulations of grand designs, or on small immediately attainable reforms of existing practices' (Wright 2009, ii). In what he calls a 'sociology of the possible', Wright develops a specific version of utopian thinking that is 
fundamentally oriented towards developing normatively grounded emancipatory alternatives to dominant social structures. This 'alternative social world' (Wright 2012, 9) involves the transformation of 'power relations within the economy in a way that deepen and broaden the possibility of meaningful democracy'. While not explicitly focusing on social innovation per se (although he does explicitly use the term to describe emancipatory alternatives), Wright appears to be almost wholly ideologically aligned with a radical tradition of social innovation. Examples of real utopias put forward by Wright include Wikipedia, participatory budgeting, worker co-operatives and public libraries (Wright 2012), which are also often used as exemplars of social innovation (see, for example, Novy and Leubolt, 2005).

The first stage of Wright's framework involves specifying a set of moral principles for judging social institutions. He notes that different moral principles can be used to animate different journeys and bases his own proposed journey on the principles of equality, democracy and sustainability. In a second stage those moral principles are then used as a basis for diagnosis and critique. In his third stage of analysis, Wright suggests developing an account of viable alternatives, (or real utopias), such as the participatory budgeting model seen in Porto Alegre (Wright 2012). A focus on the unintended consequences and tensions of existing organisations, networks and institutions provides insights into their viability, Wright argues, and thus their potential for achieving emancipatory change. The fourth stage is to propose strategies of transformation to realise alternatives. Now that we have outlined our guiding theoretical framework in detail, we next turn attention to the methodology employed in our study.

\section{Methodology}

\section{Case organisation}


Ashoka builds and cultivates a community of change leaders who see that the world now requires everyone to be a changemaker. Together, we collaborate to transform institutions and cultures worldwide, so they support changemaking for the good of all. ${ }^{4}$

Although headquartered in the United States, Ashoka operates internationally to develop networks of individuals and organisations aimed at driving social change at a systemic level. Former McKinsey consultant Bill Drayton founded Ashoka (a Sanskrit word roughly translating to 'absence of sorrow') as a non-profit in 1980 with the aim to identify, support and mobilise a network of 'leading' fellows who, after a rigorous selection process, are introduced to a 'fellowship where every member is committed to championing new patterns of social good. ${ }^{5}$ For many years Ashoka operated exclusively in the global south, mobilizing their founding team which had 'expertise and networks that spanned leading corporate, governmental and academic organizations in the United States' (Chliova, Mair, and Vernis 2020). Ashoka now has offices worldwide and, over the 40-year existence of the organisation, has selected and funded 3,500 Ashoka Fellows in 92 countries $^{6}$. Activities are financed by private individuals and foundations as well as corporations, but Ashoka explicitly state that they do not accept funding from government entities. This relates - as we will show - with their self-presentation as a change-oriented network diametrically opposed to what they delineate as 'traditional' institutions, such as governments and established NGOs which aimed to 'alleviate social problems but did not affect the systems that were the root of these problems' (Chliova, Mair, and Vernis 2020). In recent years Ashoka has deliberately expanded their focus toward the idea that 'everyone' can be a 'changemaker' (Wells 2018) rather than exclusively on the work of their Fellows.

\footnotetext{
${ }^{4}$ https://www.ashoka.org/en

5 See https://www.ashoka.org/en-gb/program/ashoka-venture-and-fellowship

${ }^{6}$ See www.ashoka.com
} 


\section{Data gathering}

Social innovation intermediaries often circulate different formats of text, such as advertisement material, newsletters and reports, to communicate their purpose and mission to a broad audience (Dey, Schneider, and Maier 2016). Websites are the most prominent method by which they communicate with their stakeholders and seek to convince, often in an aspirational manner, about the 'mission and vision' they uphold and strive for (Christensen, Morsing, and Thyssen 2013). Entries published on websites might be considered as offering a dramatised, stylised and highly scripted understanding of what the organisation does and what it stands for. However, such messages can also act as a 'call to arms' in seeking to attract followers to their cause through offering a diagnosis of what is wrong with the world, while setting out fictional expectations of a desirable future state. Despite its undeniable importance and visibility, online content has received comparatively little attention by way of discourse analyses of social innovation intermediaries (although see the work of Barraket (2019) examining the role of intermediaries within the context of social procurement). We consider that websites are

unique expressions of contemporary culture, and as such they constitute a huge repository of potential data about contemporary ways of doing and thinking of large groups of people across ethnic and national boundaries. (Pauwels 2012, 247).

Using websites as sources of information is thus expedient for understanding how intermediary organizations discursively problematise a certain aspect of the status quo in order to stage fictions or drafts of alternative future states. While Ashoka has offices (and websites) covering many regions of the world, we focused our attention on the contents of the US website hosted by the global headquarters. What is important to note, however, is that Ashoka duplicates a large portion of their web content to other national 
websites, thus creating a public image that is unitary and often repetitive, rather than contextually divergent. We downloaded single pages of the US Ashoka website into text form and imported this into the Qualitative Data Analysis computer software package NVivo. We subsequently removed blog entries, news items, and stories created by their Fellows in order that our analysis focused on permanent content, since our interest was in staged philosophies and strategies rather than implementation.

\section{Data analysis}

Inspired by Wright's critique of classical utopianism, and his envisioning of realist utopias as a morally grounded, practice-oriented mode of enacting the future, our basic aim within this study was to understand whether social innovation intermediaries produce utopias and, if so, the nature of those utopias. Since Ashoka has gained reputation as a think tank and aspirational network that seeks to impact on, or even to 'create' the future, we initially presumed utopian reasoning to be highly prevalent in their public texts. What remained unclear to us, however, was the degree to which Ashoka submits to the sense of practical utopianism that Wright proposed, and whether they engage in a process of identifying a common moral ground for their action. In accord with Wright, we presume both to be of crucial importance. Utopias need to be based on ethics, while also containing 'hard-nosed proposals for pragmatically improving our institutions' (Wright 2009, 4).

Our analysis thus takes the form of an abductive comparison (Peirce 1955; Timmermans and Tavory 2012) between the concepts that Wright subsumes under his larger theorem of realist utopias and our empirical material: the public, ostensibly utopian statements of Ashoka. Abduction in this context means to engage in an analysis that is neither purely inductive - since we feed theoretical pre-knowledge into the process - nor purely deductive, because we allow concepts to emerge from the data. 
Thus, we moved back and forth between the textual material and Wright's theory, engaging in a hermeneutic process that sustains some degree of openness, eventually leading to new insights, while simultaneously testing the applicability of previously developed knowledge (Reichertz 2010). The direction of our analysis moved first from a theory-informed initial grasp of the data towards Wright's theory, and then back from his theory to the data in order to understand the degree to which his concepts match the argumentative structure of Ashoka's claims. The following sections provide a stepwise account of the methodological process and the insights gained through it.

In a first round of open coding, roughly oriented towards identifying utopian aspects in Ashoka's discourse, we identified two guiding themes: 'problem statements' (what is wrong with the world) and 'utopian visions' (imaginations of a better world). This discovery of an issue-solution logic of argument first led us to literature on real utopias, and particularly the work of Wright. Our superficial observation was that both Ashoka and Wright were engaging in a process of defining contemporary societal problems and then identifying desirable alternative states. However, further analysis revealed major differences between Ashoka's framing of utopias and Wright's ideals, which centre on collective action and democratic participation.

In our second round of coding (now moving back from theory to data), we analysed the dataset with a view to Wright's four steps of moral principles; diagnosis and critique; viable alternatives; and what he calls a 'theory of transformation' for realising those alternatives (which we refer to as transformation strategies to assist understanding). However, we adopted Wright's approach for our own purposes: rather than critiquing Ashoka against the moral principles proscribed by Wright (namely democracy, equality and sustainability), we sought to identify the moral principles that Ashoka themselves adhere to. We creatively re-interpreted diagnosis and critique as Ashoka's own 
diagnosis and critique of what is wrong with the world (i.e. problem statements) and viable alternatives as akin to the utopian (writ small) vision proposed by Ashoka, namely 'everyone a changemaker'. Our focus was thus on what Ashoka do (or aspire to do), rather than on the actions of their Fellows. At this stage, we engaged in focused, i.e. theme-guided, coding in order to direct our investigation to the manifest content of semantic themes as they pertain to Wright's framework discussed above. In line with content analysis, we tried to stay as close to the data as possible by line-by-line coding each page thematically to the four broad themes. However, we quickly realised that the data did not allow us to clearly distinguish between signifiers of moral principles (agreed-upon standards of moral judgment) and critique and diagnose (an examination of whether existing institutions adhere to these principles). The 'problem statements' that we earlier found to be highly prevalent in Ashoka's discourse turned out to merge moral principles within their diagnoses of problems. To illustrate, rather than engaging in a process of identifying the commons - agreed-upon shared values such as democracy, equality or sustainability - Ashoka proceed directly to identify problems (thus 'problem statements') worthy of address.

As we will discuss along with the presentation of our results, the other stages of viable alternatives and transformation strategies similarly contained moral positions that were not openly stated, but identified from the way that Ashoka frames their perspective on reality, their motivations to intervene in order to create a different reality, and their propositions of how to do so. This merger works against Wright's emphasis to first specify moral principles before taking imaginative action upon them. Using Wright's procedure as a point of vanguard to assess the ethics and practical orientation of utopian discourses, we dedicated our analysis to carving out the deeper moral implications of Ashoka's public rhetoric. This involved re-reading the quotes within their wider context 
to gain a better understanding of not just what was said, but to interpret why it was said, and how individual themes relate to each other. This allowed us to contextualise general patterns of meaning, while also permitting us to ignore text passages that were not immediately relevant for our analysis. In this way, we sought to contribute to progressive conversation on social change and social innovation as a contested concept (Ayob, Teasdale, and Fagan 2016; Ziegler 2017).

\section{Findings}

Our findings are organised according to three parts derived from attempting to combine Wright's schema with the themes emerging from our more inductive open coding, namely: 1) Ashoka's problem statement (Wright's critique and diagnose, albeit without a prior clarification of moral principles); 2) utopian vision (the viable alternative that Ashoka seeks to create, which necessarily merges the putative moral principle: 'everyone a changemaker'), and; 3) transformation strategies (how they seek to reach their utopian visions). In practice, these stages were not so simple to parse from the data, and inevitably overlap to some degree.

\section{The new reality: Unfit for change}

As we indicated, Ashoka inherently avoid negotiation over the moral grounding of social innovation, instead weaving a sense of a universal morality into their problem construction. In this section we identify the basic terminology and reasoning that Ashoka adopt when talking about global issues to be addressed, while also attending to the hidden moral claims inherent to this reasoning.

The basic trope that Ashoka use in their references to problems is that of change: a term that here refers both to a given reality of radical transformations in the world, and the 
mode in which to act upon this reality. Social innovation is itself perceived a process of change. In Ashoka's words:

We are living in a truly historical turning point as a world that has largely been defined by repetition is replaced by one defined by its opposite, change. The rate of change and the extent of interconnection, each multiplying the other, in the world have been accelerating exponentially for at least 300 years. Globalization and technological innovation connect us in unprecedented ways, lowering barriers and allowing everyone to participate.

The image of an accelerated reality echoes on-going debates about how technologydriven disruptive changes not only alter the tempo of production (Rosa, 2013), but also reinforces structural inequalities (Zuboff 2019). However, for Ashoka, the 'new inequality' is caused not by capitalism, but rather by some people not having the necessary skillset to cope with change:

Much of the world's population has learned how to contribute to and adapt to change and how to be effective members of the ever-changing, open teams of teams that are how this new reality is organized. Moreover, they help one another become better changemaking players as the game accelerates - because that is critical both for team success and personal happiness. This portion of humanity is doing very well. However, the very large other part of society does not have the changemaking skills needed to play in today's new reality where everything is changing ever faster. The result: The world is sharply and increasingly divided by a new inequality.

Under conditions where the temporal structure of society is accelerated, Ashoka repeatedly claim that existing institutions, including educational institutions, are failing since they are based on outdated models:

Much of the world is stuck in a management model that is based on teaching people specialized skills that they repeat over and over as part of rigid hierarchies.

While the (new) social sector may have the answers, philanthropy and foundations have so far proved unable to globalise these solutions:

Great business ideas go global to serve customers around the world. By contrast, no such market forces are at work in the social sector. Social innovation too 
often remains local or national. Although many of the ideas and the entrepreneurs behind them have the potential for global spread, the social sector still lacks a process that focuses specifically on the global scope of change and the resources and mechanisms necessary for globalizing an idea successfully.

That the world is changing at a staggering rate is not necessarily framed as problematic. The problems lie, rather, in that people are ill-equipped to cope with the acceleration spiral of which they are part, and that the social sector is (currently) unable to globalise its solutions. In this spirit, Ashoka do recognise a problem of inequality. However, rather than exploring how frantic acceleration causes inequality and how this could potentially be solved (perhaps by government), inequality is reduced to a lack of 'sophisticated skills' that are required to counteract - as a changemaker - the negative effects of a rapidly changing world.

We thus observe a certain narrowness in the way Ashoka frames the 'problems' to be tackled through social innovation. Their problem-framing accepts change and the inequality produced by change as a manifest reality and starting point, thus engaging in a form of diagnosis (Wright's second step) which effectively conceals undergirding moral principles (Wright's first step) by presenting the reality and 'issues' we face as undebatable and given. By strategically placing their own action in contrast to the working of 'traditional philanthropy', Ashoka also sweeps away a conventional emphasis on grounding social interventions on ideals of justice and obligation (as matters of rights). Rather, as we saw above, Ashoka's problem statements tend to bypass the open definition of moral principles altogether, and with it also the (potential) role of government. Thus, Ashoka avoids adopting a transformative social innovation approach that aims at creating a common moral ground and shared knowledge of societal problems and demands engagement with the political failures or complex structural reasons behind these problems. While there are occasional references to transforming the social sector in order that social innovation can be 'scaled', the narrow 
problem-framing positions social innovation in its utilitarian sense which demands a technocratic solution (Montgomery 2016). If the (solvable) problem is reduced to a lack of sophisticated skills, then, as our next section identifies, the technical solution lies in providing people with the changemaking skills necessary to cope in the new world.

\section{Utopian Vision: Everyone a Changemaker}

In response to their diagnosis of the 'new inequality' deriving from acceleration, Ashoka's viable alternative involves the creation of a new 'mindset' in individuals that helps them to envision, plan, and enact change. They ought to become 'changemakers'. The changemaker who evolves from Ashoka's account is a utopian personality well equipped for dealing with the new, i.e. accelerating, reality. Thus, Ashoka proposes improving the capabilities of people and ultimately creating a world in which everybody is in track with change, and creating change herself:

Ashoka envisions a world in which everyone is a changemaker: a world where all citizens are powerful and contribute to change in positive ways.

Such a universal call for individual adaptation most clearly evolves from Ashoka's slogan 'Everyone a changemaker', the proposition that comes closest to a moral principle (in terms of Wright's schema).

While this phrase often appears in the form of a slogan on their webpage, its ambition also emerges from implicit formulations such as 'entrepreneurs in every corner in the world,' and demands 'everyone to be able to contribute.' Ashoka tread a path between conceptualising changemakers as 'unique individuals' and treating changemaking as a skillset that can be taught to everybody. Hence changemakers have special skillsets that include quasi-naturalistic qualities such as cognitive empathy: 
This, the foundational skill, which must be mastered in childhood and continuously developed thereafter, requires one's cerebral cortex and one's mirror neurons ('I feel your pain') learning to work together consciously to understand and map the world's fast morphing kaleidoscope of people and contexts. Without this, one will hurt others and disrupt groups - and therefore be pushed aside. (It is no longer possible to be a good person by diligently following the rules because, as change accelerates, they cover less and less.)

However such quasi-naturalistic attributes (which can, fortunately, be mastered in childhood) are combined with more practical skills such as teamwork, leadership and being able to grasp the bigger picture and identify patterns of change. The practical side of Ashoka's utopianism thus takes the form of calls for cultivating within oneself certain personality traits, while developing the type of leadership skills commonly taught in business schools.

The depictions of ideal character traits hint at the highly individualising, or even psychologising, tendencies inherent to Ashoka's discourse: tendencies that awkwardly mingle with other narratives that lend a certain universalism or democratic appeal to changemaking. On the one hand, changemakers evolve as extraordinary people occupying unique skills, as evident in the above list of traits and the competitive process that Ashoka has installed to elect their Fellows. On the other, Ashoka nods toward egalitarianism through proposing that everybody can become such an outstanding individual. 'Everyone a changemaker' combines reference to equal consideration of 'everyone' (in this sense reminiscent of Wright's notion of equality), with an individualcentred idea of practical autonomy that 'requires' everyone to develop skills for adapting to this 'new reality'.

What is remarkable about Ashoka's rhetoric around changemaking is that while they invest efforts into demystifying who a changemaker is (a powerful citizen who creates positive change), it remains vague and unclear what a 'just world' would look like. Nor is there any discussion of moral principles (such as democracy, sustainability or equality 
in a more comprehensive sense) upon which such a just world could be built ${ }^{7}$. In essence, their utopian vision concerns the creation of ideal persons, rather than the ideal state of the society that people ought to live in. This might suggest that the world, according to Ashoka, will look exactly as it does now (speeding ahead), but people will be better equipped to cope with or adapt to it:

Now society needs everyone to be ready to thrive in a world of constant, rapid, exponential change as a skilled changemaker. It needs every young person, parent, and educator to grasp this new paradigm for success in growing up and in life.

While there are occasional references to transforming institutions (which we will discuss in more detail in the next section), it is notable that such transformations mainly focus on working with schools and universities to help them better teach changemaking skills. Thus, there is no place for the 'institutional' utopias that Wright has in mind when he calls for examination of how existing systems could be different. This can be seen in Ashoka's tendency to use traditional philanthropy as a contrast foil:

Unlike traditional philanthropists...changemakers...fully apply their creativity, energy, and connections to effect positive social change.

While Ashoka envision changemakers in the role of institutional entrepreneurs or intrapreneurs who create change from within, their discourse lacks a more comprehensive, moral grounding that provides a basis for critiquing institutions in order to then develop viable alternatives (how social institutions could be different) in response to this critique (Wright 2012). As a consequence, the positive social change that changemakers could affect remains vague and unspecified.

\section{Transformation Strategies}

\footnotetext{
7 We performed a keyword search for democracy, sustainability and equality. The only mention of equality related to challenging 6,000 poor students to create ventures, which would, they argue, empower them and lead to 'true equality'. Democracy was not used at all. Sustainability was used twice, in relation to achieving a sustainable work/life balance.
} 
We next turn attention to the routes by which Ashoka indicate that they will achieve their utopian vision of change. We label these developing heroes; networks and collaborations; transforming existing institutions; and trickling down. They can be seen to operate in a relatively linear fashion, meaning that, taken together, they approximate to a stepwise transformation strategy. We discuss each of the steps in turn.

Firstly, in many places on Ashoka's website, they present accounts of how they develop heroes by investing into establishing a network of Ashoka Fellows:

We find and cultivate social entrepreneurs in every corner of the world, whose system-changing innovations solve deep-rooted social problems...Ashoka Fellows are the ultimate role models in today's world.

In other words, Ashoka's initial step towards change is to 'identify', 'select' and 'cultivate' people who can, in their view, become the world's leading social change agents. Fellows receive grants to pursue their ideas along with coaching. This identification and support system for Fellows has been at the core of Ashoka's approach to social innovation for 40 years (Wells 2018).

This model of talent spotting and developing heroes has more recently adapted to the education system through a program called 'AshokaU'. This they depict as

Ashoka U's flagship program [which] recognizes colleges and universities around the world that have embedded social innovation as a core value and showcases the ways in which they have built supportive environments for changemaking across their institutions. (our emphasis)

Thus, heroes can be individuals or educational institutions that embrace and support the spread of social innovation as a concept. The formulation 'social innovation as a core value' reinforces our earlier observation that Ashoka avoid developing open moral imperatives, instead subscribing to the narrow ideal that institutions and personalities across the world adopt the social innovation mindset. Social innovation thus involves embodying an innovating habitus that is itself seen as morally valuable. 
A second theme relates to creating new networks and collaborations. A large array of web content contains references to new ways of organising through 'fluid open teams'. Such language indicates how Ashoka shift from a traditional vocabulary of technical cooperation to notions of sharing, enacted by visual metaphors of flow, dynamism and openness:

Living and working in our changemaker world requires breaking through silos, tearing down walls, and organizing in fluid, open, teams of teams.

These fluid open teams seem to embrace horizontal models of organizing, whereby networks evolve around common goals through 'teams of teams':

When individuals and organizations cross old boundaries and align toward a shared goal, they form a 'team of teams,' unlocking massive amounts of social — and often business - value.

Ashoka thus avoid operating with classical demarcations between sectors, instead proposing social innovation as a trans-sectoral and transdisciplinary mindset that unites people with different backgrounds and fields of expertise. They claim to collaborate with 'institutions and cultures' worldwide, in order to 'create initiatives with both local and global impact.' Upon closer analysis, however, we noticed a privileging of corporate partners over public institutions. Their main emphasis lies on involving private firms, educational institutions and foundations, with just one reference to working with policymakers. This is perhaps unsurprising given that one strand of social innovation/entrepreneurship discourse positions such approaches as an alternative to 'inefficient and outmoded' government bureaucracy (see Dey and Teasdale, 2016) and that Ashoka explicitly distance themselves from accepting government funding. Interestingly, in tension with the horizontal, eye-level mode of work they seem to propose, they also position themselves at the heart of the networks they create, since such networks are built within the Ashoka family: for example, the AshokaU network of universities. 
Third, even though bracketing the role of the state from their utopian project, Ashoka suggest that entrepreneurial interventions transform institutions, although with a limited view on the kind of institutions that they view as ready for transformation. Ashoka's model of social transformation thus envisions that Fellows 'teach' institutions how to enable society to 'flourish':

Ashoka social entrepreneurs serve as role models and provide the how-tos that enable individuals, organizations, and whole societies to flourish in a world of rapid change.

Through their networked position in a meta-community of social innovators, Ashoka claim that their Fellows are ideally positioned to 'collaborate to transform institutions and cultures worldwide, so they support changemaking for the good of society.'

Much of Ashoka's emphasis lies on schools and universities, not only as breeding grounds for changemakers, but also as targets for 'big changes in the way young people experience education'. This leads us to the fourth theme that we identified as a transformation strategy in Ashoka's roadmap to Utopia: trickling down from Fellows. This is most prominent in relation to education. Seemingly, once educational institutions have been transformed, these institutions can then leverage their influence on students to scale their reach significantly. It thus appears natural, or even urgent, to Ashoka that changemaking becomes an obligatory element in higher education; a basic toolkit that young people should be equipped with before approaching their working lives as institutional entrepreneurs. Crucial components of this toolkit are the special character traits that we introduced before:

At Ashoka Changemaker Schools, students are learning the essential skills of empathy, creativity, thoughtfulness, leadership, and teamwork.

The utopian desire inherent to the cooperation with educators is that social innovation ought to become the predominant mode by which young people approach the world. 
Trickling down thus not only refers to a strategy of transformation of the 'actual world', but mainly an intervention into the ways that future elites will view 'problems' and thus the correct (technical) way to act to act upon them.

In a similar manner, Ashoka also work directly with high level executives through pairing their Ashoka Fellows with corporate executives through the Ashoka Globalizer program. This allows them to scale their approach, as the corporate executive (or Globalizer) is encouraged to examine innovative ways to scale their influence and impact:

These business leaders help the Fellows reflect on key issues and establish a solid strategy to spread their impact. The Globalizer also identifies underlying patterns in innovative solutions and disseminates them, empowering social entrepreneurs everywhere to develop more effective strategies to spread their impact.

As a final stage, the transformed institutions and high-level executives are expected to transform those working for them to achieve social change. The Globalizer model indicates that Ashoka's transformation strategy combines fluid and open work with a more hierarchical approach, whereby the 'heroic' (Ruebottom 2013) Fellows sit at the top of the hierarchy and use teams to impart their expertise to an influential 'middle class' of changemakers through transforming their institutions and creating new networks. Such 'trickling down' shows that Ashoka's transformation route map relies on heroic leaders providing the inspiration for humbler, more ordinary, changemakers to follow. Ashoka Fellows and Ashoka themselves provide the thought leadership and inspiration, while eventually, via trickling down processes, the masses will be trained to cope with the new world.

\section{Discussion and Conclusions}


Based on a real utopian-inspired analysis of Ashoka's discourse, we set out to explore how Ashoka frame the processes involved in potentially guiding us to a better future. There are, of course, methodological limitations to our study: the method we employed can only provide a snapshot of current discourses, rather than how such discourses have evolved or shifted over time. Websites are continually updated, and we cannot say much, if anything, about the stability or dynamism of their messages. Furthermore, understudied areas such as 'modes of conviction' of social innovation actors are considered to be found in 'the 'extra-textual'... such as aesthetic significance, emotional fervour, spiritual dynamism and sensual pleasure' (Mauksch 2017, 133) and thus cannot be revealed by the method we employed. Moreover, our focus has been on Ashoka, and not the individuals and organisations it supports across the world i.e. notably the Ashoka Fellows or the universities participating in AshokaU. Notwithstanding these limitations, and while appreciating Ashoka's global call to action, we see a range of issues with the procedures that lead Ashoka, if we take Wright's real utopias seriously, towards a form of utopian thinking which, we believe, rests shakily on a very narrow moral principle.

First, the organisation seems to adopt a narrow, individual-centred focus on a process of transformation, rather than developing a Utopia of/for social innovation. In this way, Ashoka takes a more cautious approach that eschews Utopian blueprints, consistent with contemporary research on utopias. As our analysis has revealed, Ashoka's commitment starts from the premise that the world is changing quickly, and we are illequipped to cope unless we all submit to changemaking as a new guiding principle. Despite a narrative emphasis on the need for 'radical' and 'urgent' improvement contained in their changemaking project, Ashoka's vision evades engagement with fantasies or utopian (writ small) dreams. Ashoka adopts a utilitarian approach to social 
innovation, since they do not spell out a clear vision of a superordinate 'common good', an associated socio-political vision, or more comprehensive moral principles. Far more modestly, teaching everyone to be a changemaker hints at an endpoint whereby people, and not necessarily systems or structures, should transform. Instead of promoting a radically alternative vision of how the world should be, Ashoka aspire to support and teach people how to deal with the world as it is, but under the stewardship of inspirational leaders (i.e. Ashoka Fellows). In effect, Ashoka allude to transformational social change, but the model of changemaking indicated from their discourse relates, rather, to adapting to the status quo.

Second, in their glamorisation of 'changemakers', Ashoka sidestep a collective process in which people are encouraged to use their reason to liberate themselves from systems of oppression and exploitation, potentially reinforcing the status quo. There is, at first sight, a relationship between the principle of changemaking and Wright's principle of democracy, in that 'everyone a changemaker' can be interpreted as a way of empowering actors from diverse social, educational and national backgrounds. In proposing the development of skills required for participation in late capitalism, changemaking seemingly creates a new variation of a fairly old idea: equal participation in decisions that affect one's life (to draw on Martha Nussbaum's (2007) formulation of this capability). However, through a strong focus on the production of heroes, Ashoka eschew direct reference to the language of participation. It remains unclear at what stage (if any) Ashoka engage in democratic processes whereby individuals and groups targeted by their changemaking are able to agree upon the relational, participatory or democratic processes to, or outcomes of, emancipation. This is not to say that individual Fellows do not adopt such an approach, simply that this does not seem to be inherent to Ashoka's changemaking model. Thus, despite emphasising a particular version of 
autonomy and participation (i.e. 'everyone a changemaker'), Ashoka's vision may work to deny the marginalised groups, who are the implicit target of their social innovation approach, voice to define their own 'moral principles' and 'viable alternatives'. There is an absence of joint rule-making that Wright considered to be the essential mode in which utopian thinking should work. Avoiding any sort of antagonistic struggle, such as that between labour and capital in socialism, Ashoka instead argue that 'they' - the least-advantaged (who lack the skills to accelerate) - should all become like 'us', since 'there is no alternative' to limitless adaptability. Ashoka thus offer a combination of a conventional (largely capitalist-entrepreneurial) worldview with a 'new' principle that gestures at a dystopian transformation: adapt or perish. They present this end state of inducing a habitus of change in everyone as desirable, without offering a convincing moral justification of why (adaptation to) acceleration should be considered desirable in the first place (Gardiner 2017).

Thirdly, Ashoka accept acceleration as a reality that cannot (and must not) be changed. As far as Ashoka prepare people to surf the rhythms of accelerated life, it is arguable that the motto/logo 'everyone a changemaker' works mainly as a survival guide under conditions of 'liquid life', characterised by a persistent pressure to keep up with the latest trends, fashions and changes (Bauman 2007). This naturalistic fallacy obfuscates that acceleration is not a law of nature but a human accomplishment which can, in principle, be altered. The ideological strength of the idea of acceleration as a stable (and increasing) trend is that it reinforces itself as truth. This argument diverts attention from the negative ramifications of acceleration, since acceleration is a seeming precondition for the reproduction of current levels of affluence. So, even if the negative side of acceleration is acknowledged, deep-seated, 'common-sense' beliefs about the naturalness and necessity of acceleration prevent us from critiquing it. 
Fourth, and further to the previous point, the presentation of acceleration as fact has performative effects on what we perceive as 'real'. The changemaker story of living with, and in some way shaping, the acceleration processes, is a story that attracts others to support Ashoka materially and to provide it with legitimacy. This story fits well with the business plan of Ashoka, which, by its own mandate, is only supported by individuals, private foundations and business entrepreneurs. In other words, the 'winners' (Giridharadas 2019) of acceleration are provided with a story that ultimately justifies and reinforces their position. The structural implication, however, is that Ashoka's approach to social innovation is utilitarian rather than transformative, since we assume it unlikely that this group of investors will fund alternatives to living in an accelerated world of capitalism. Through the transformation strategies identified above, funders ultimately support Fellows to transform schools and universities and create the changemakers of the future. This circular process, we argue, reinforces the hierarchies (the 'new inequality') that Ashoka ostensibly sets out to overcome, rather than moving closer to the principles of equality and democracy that Wright (and to some degree Ashoka themselves, in their depiction of 'everyone'), claims should guide utopian thinking.

At this point, it might reasonably be objected that Ashoka is not talking about capitalism but about a 'new reality' that it seeks to tackle 'regardless of the nature of the economy or of ideology ${ }^{8}$. A more sympathetic reading then might suggest that Ashoka do not consider it their place to impose their own ideology or vision of utopia on anyone; rather, they see themselves as 'politically neutral' (consistent with their nonprofit status) and merely seek to give everyone the tools and power to create their own utopias. A more critical reading, however, reveals that the very vagueness of their approach to

\footnotetext{
${ }^{8}$ https://www.ashoka.org/en-us/story/new-reality
} 
social innovation serves a particular function. If 'social change' or 'social innovation' are not clearly articulated then they can, somewhat paradoxically, 'command affective thrust from individuals with a wide range of interests and values, since they represent a positively connoted aspect of western common sense' (Dey, Schneider, and Maier 2016, 1458), while detracting attention from the lack of clear moral grounding. Such vagueness serves as an 'idealising function' (Fotaki 2010), which empties signifiers such as 'social change' of their specific meaning (Dey, Schneider, and Maier 2016). Crucially, however, vagueness also allows particular political and cultural presuppositions to be folded unproblematically into 'business as usual', strengthening the hegemonic capacity of capitalism, while failing to recognise the complexities of the world it seeks to impose itself on.

Our findings therefore lead us to the conclusion that the collaborative discourse of social innovation, as practised by Ashoka, eventually equates to learning to cope with dystopia. Despite the 'everyone a changemaker' rhetoric, the aim is less to change the world, and more to adapt to it, its shortcomings, and its frenetic pace of change. It was the late Mark Fisher (2009) who powerfully stated that it was 'easier to imagine the end of the world than the end of capitalism'. As this paper suggests, even apparently alternative fictional expectations can be incorporated into capitalism. Perhaps the reframing of alternative forms of organising as 'utopian' (nowhere) and a societal promotion of the market utopia as 'real' (no alternative) takes perfect form in the way that Ashoka guide us to a better future through elite-led strategies that eventually rely on transforming education systems to trickle down the message that there is no alternative. 


\section{References}

Anheier, Helmut K., Gorgi Krlev, and Georg Mildenberger, eds. 2019. Social Innovation: Comparative Perspectives. Routledge Studies in Social Enterprise \& Social Innovation. Abingdon, Oxon: Routledge. https://socialinnovationexchange.org/sites/default/files/uploads/9781351655354 - $0 . p d f$.

Ayob, Noorseha, Simon Teasdale, and Kylie Fagan. 2016. 'How Social Innovation "Came to Be": Tracing the Evolution of a Contested Concept'. Journal of Social Policy 45 (4): 635-653. doi:10.1017/S004727941600009X.

Barberá-Tomás, David, Itziar Castelló, Frank G. A. de Bakker, and Charlene Zietsma. 2019. 'Energizing through Visuals: How Social Entrepreneurs Use EmotionSymbolic Work for Social Change'. Academy of Management Journal 62 (6): 1789-1817. doi:10.5465/amj.2017.1488.

Barraket, Jo. 2019. 'The Role of Intermediaries in Social Innovation: The Case of Social Procurement in Australia'. Journal of Social Entrepreneurship, June. doi:10.1080/19420676.2019.1624272.

Bauman, Zygmunt. 2007. Liquid Times: Living in an Age of Uncertainty. Cambridge: Polity Press.

Beckert, Jens. 2016. Imagined Futures: Fictional Expectations and Capitalist Dynamics. Cambridge, Massachusetts: Harvard University Press.

Bloch, Ernst. 1995. The Principle of Hope. Translated by Neville Plaice, Stephen Plaice, and Paul Knight. Studies in Contemporary German Social Thought. Cambridge, MA: MIT Press.

Brandsen, Taco, Sandro Cattacin, Adalbert Evers, and Annette Zimmer, eds. 2016. Social Innovations in the Urban Context. New York, NY: Springer Science+Business Media, LLC. https://link.springer.com/content/pdf/10.1007\%2F978-3-319-21551-8.pdf.

Chliova, Myrto, Johanna Mair, and Alfred Vernis. 2020. 'Persistent Category Ambiguity: The Case of Social Entrepreneurship'. Organization Studies, January. doi:10.1177/0170840620905168.

Christensen, Lars Thøger, Mette Morsing, and Ole Thyssen. 2013. 'CSR as Aspirational Talk'. Organization 20 (3): 372-393. doi:10.1177/1350508413478310.

Claeys, Gregory, and Lyman Tower Sargent. 2017. The Utopia Reader, 2nd edition. New York: NYU Press.

Dey, Pascal, and Othmar Lehner. 2016. 'Registering Ideology in the Creation of Social Entrepreneurs: Intermediary Organizations, "Ideal Subject" and the Promise of Enjoyment'. Journal of Business Ethics 142 (4): 753-767. doi:10.1007/s10551016-3112-z.

Dey, Pascal, Hanna Schneider, and Florentine Maier. 2016. 'Intermediary Organisations and the Hegemonisation of Social Entrepreneurship: Fantasmatic Articulations, Constitutive Quiescences, and Moments of Indeterminacy'. Organization Studies 37 (10): 1451-1472. doi:10.1177/0170840616634133. 
Evers, Adalbert, Benjamin Ewert, and Taco Brandsen. 2014. Social Innovations for Social Cohesion: Transnational Patterns and Approaches from 20 European Cities. Liege: WILCO Consortium/EMES. www.wilcoproject.eu.

Fernando, Julian W., Nicholas Burden, Adam Ferguson, Léan V. O’Brien, Madeline Judge, and Yoshihisa Kashima. 2018. 'Functions of Utopia: How Utopian Thinking Motivates Societal Engagement'. Personality and Social Psychology Bulletin 44 (5): 779-792. doi:10.1177/0146167217748604.

Fisher, Mark. 2009. Capitalist Realism: Is There No Alternative? Ropley, Hants: Zero Books.

Fotaki, Marianna. 2010. 'Why Do Public Policies Fail So Often? Exploring Health Policy-Making as an Imaginary and Symbolic Construction'. Organization 17 (6): 703-720. doi:10.1177/1350508410366321.

Gardiner, Michael E. 2017. 'Critique of Accelerationism'. Theory, Culture \& Society 34 (1): 29-52. doi:10.1177/0263276416656760.

Giridharadas, Anand. 2019. Winners Take All: The Elite Charade of Changing the World. London: Penguin.

Godin, Benoit. 2012. Social Innovation: Utopias of Innovation from c.1830 to the Present. Montréal: Working Paper 11 Project on the Intellectual History of Innovation. http://www.csiic. ca/PDF/SocialInnovation_2012.pdf.

Hahnel, Robin, and Erik Olin Wright. 2016. Alternatives to Capitalism: Proposals for a Democratic Economy. London; New York: Verso.

Hedges, Chris. 2020. 'The Disaster of Utopian Engineering'. Truthdig: Expert Reporting, Current News, Provocative Columnists.

https://www.truthdig.com/articles/the-disaster-of-utopian-engineering/.

Jessop, Bob, Frank Moulaert, Lars Hulgård, and Abdelillah Hamdouch. 2013. 'Social Innovation Research: A New Stage in Innovation Analysis?' In International Handbook on Social Innovation: Collective Action, Social Learning and Transdisciplinary Research, edited by Frank Moulaert, 110-130. Cheltenham: Edward Elgar Publishing Ltd.

Lepore, Jill. 2014. 'The Disruption Machine'. The New Yorker June 23.

Levitas, Ruth. 2000. 'For Utopia: The (Limits of the) Utopian Function in Late Capitalist Society'. Critical Review of International Social and Political Philosophy 3 (2-3): 25-43. doi:10.1080/13698230008403311.

Levitas, Ruth. 2013. Utopia as Method: The Imaginary Reconstruction of Society. Houndmills, Basingstoke, Hampshire: Palgrave Macmillan.

Levitas, Ruth. 2017. 'Where There Is No Vision, the People Perish: A Utopian Ethic for a Transformed Future'. Centre for the Understanding of Sustainable Prosperity. http://www.cusp.ac.uk/wp-content/uploads/05-Ruth-Levitas-Essay-online.pdf.

Mannheim, Karl. 1985. Ideology and Utopia: An Introduction to the Sociology of Knowledge. San Diego: Harcourt Brace Jovanovich.

Mauksch, Stefanie. 2017. 'Managing the Dance of Enchantment: An Ethnography of Social Entrepreneurship Events'. Organization 24 (2): 133-153. doi: $10.1177 / 1350508416644511$. 
McBeath, Graham, and Stephen A. Webb. 2000. 'On the Nature of Future Worlds? Considerations of Virtuality and Utopias'. Information, Communication \& Society 3 (1): 1-16. doi:10.1080/136911800359392.

Montgomery, Tom. 2016. 'Are Social Innovation Paradigms Incommensurable?' Voluntas: International Journal of Voluntary and Nonprofit Organizations 27: 1979-2000. doi:10.1007/s11266-016-9688-1.

Moulaert, Frank., Flavia Martinelli, Erik Swyngedouw, and Sara Gonzalez. 2010. Can Neighbourhoods Save the City?: Community Development and Social Innovation. Abingdon, Oxon: Routledge.

Nicholls, Alex. 2010. 'The Legitimacy of Social Entrepreneurship: Reflexive Isomorphism in a Pre-Paradigmatic Field'. Entrepreneurship Theory and Practice 34 (4): 611-633.

Nicholls, Alex, and Alex Murdock. 2012. 'Introduction: The Nature of Social Innovation'. In Social Innovation: Blurring Boundaries to Reconfigure Markets, edited by Alex Nicholls and Alex Murdock, 1-32. Houndmills, Basingstoke, Hampshire: Palgrave Macmillan.

Novy, Andreas, and Bernhard Leubolt. 2005. 'Participatory Budgeting in Porto Alegre: Social Innovation and the Dialectical Relationship of State and Civil Society'. Urban Studies 42 (11): 2023-2036. doi:10.1080/00420980500279828.

Nussbaum, Martha C. 2007. Frontiers of Justice: Disability, Nationality, Species Membership. Cambridge, MA: Belknap Press: An Imprint of Harvard University Press.

Osborne, Stephen P., and Louise Brown. 2011. 'Innovation, Public Policy and Public Services Delivery in the UK. The Word That Would Be King?' Public Administration 89 (4): 1335-1350. doi:10.1111/j.1467-9299.2011.01932.x.

Pauwels, Luc. 2012. 'A Multimodal Framework for Analyzing Websites as Cultural Expressions'. Journal of Computer-Mediated Communication 17 (3): 247-265. doi:10.1111/j.1083-6101.2012.01572.x.

Peirce, Charles S. 1955. Philosophical Writings of Peirce. New York: Dover Publications Inc.

Pol, Eduardo, and Simon Ville. 2009. 'Social Innovation: Buzz Word or Enduring Term?’ The Journal of Socio-Economics 38 (6): 878-885.

Reichertz, Jo. 2010. 'Abduction: The Logic of Discovery of Grounded Theory'. Forum Qualitative Sozialforschung/Forum: Qualitative Social Research 11 (1).

Rogers, Everett M. 1962. Diffusion of Innovations. New York, N.Y.: Free Press.

Ruebottom, Trish. 2013. 'The Microstructures of Rhetorical Strategy in Social Entrepreneurship: Building Legitimacy Through Heroes and Villains'. Journal of Business Venturing 28 (1): 98-116. doi:10.1016/j.jbusvent.2011.05.001.

Sargent, Lyman Tower. 2010. Utopianism: A Very Short Introduction. Very Short Introductions 246. Oxford: Oxford University Press.

Sørensen, Bent Meier. 2008. "“Behold, I Am Making All Things New”: The Entrepreneur as Savior in the Age of Creativity'. Scandinavian Journal of Management, Recreating/Recontextualising Entrepreneurship, 24 (2): 85-93. doi:10.1016/j.scaman.2008.03.002. 
Timmermans, S., and I. Tavory. 2012. 'Theory Construction in Qualitative Research: From Grounded Theory to Abductive Analysis'. Sociological Theory 30 (3): $167-186$.

Urama, Kevin C, and Ernest A Acheampong. 2013. 'Social Innovation Creates Prosperous Societies'. Stanford Social Innovation Review Summer 2013. https://ssir.org/articles/entry/social_innovation_creates_prosperous_societies.

van der Have, Robert P., and Luis Rubalcaba. 2016. 'Social Innovation Research: An Emerging Area of Innovation Studies?’ Research Policy 45 (9): 1923-1935. doi:10.1016/j.respol.2016.06.010.

von Jacobi, Nadia, Daniel Edmiston, and Rafael Ziegler. 2017. 'Tackling Marginalisation through Social Innovation? Examining the EU Social Innovation Policy Agenda from a Capabilities Perspective'. Journal of Human Development and Capabilities 18 (2): 148-162. doi:10.1080/19452829.2016.1256277.

Wells, Diana. 2018. 'From Social Entrepreneurship to Everyone a Changemaker: 40 Years of Social Innovation Point to What's Next'. Social Innovations Journal, November. https://socialinnovationsjournal.org/editions/issue-52/108-introarticles/2906-from-social-entrepreneurship-to-everyone-a-changemaker-40years-of-social-innovation-point-to-what-s-next.

WEtech Alliance. 2016. 'Social Innovation'. https://www.wetech-alliance.com/socinn/.

Wright, Erik Olin. 2009. Envisioning Real Utopias. London; New York: Verso.

Wright, Erik Olin. 2012. 'Transforming Capitalism through Real Utopias'. American Sociological Review XX (X): 1-25.

Ziegler, Rafael. 2017. 'Social Innovation as a Collaborative Concept'. Innovation: The European Journal of Social Science Research 30 (4): 388-405. doi:10.1080/13511610.2017.1348935.

Ziegler, Rafael. 2019. 'The Times of Social Innovation-Fictional Expectation, Precautionary Expectation and Social Imaginary'. In A Research Agenda for Social Entrepreneurship, edited by Anne De Bruin and Simon Teasdale, 164176. Cheltenham: Edward Elgar Publishing Ltd.

Zuboff, Shoshana. 2019. The Age of Surveillance Capitalism: The Fight for a Human Future at the New Frontier of Power. London: Profile Books. 